\title{
Appetite for Destruction: On Naomi Klein's Neo-liberal Utopia-Dystopia
}

\author{
Mark Featherstone
}

\section{Introduction}

I think that there have been three definitive texts on the social, political, and economic condition of globalisation written since the year 2000. In this paper I propose to critically review the latest of these texts, Naomi Klein's Shock Doctrine (2007). But before I consider Klein's book I want to situate it in relation to what I think are the other two essential works on the global condition in the 21 st century. Let us start with what I believe to be the first of these epochal books, Hardt and Negri's Empire (2000). Empire was published to massive critical and popular acclaim and quickly became a central text in the wider effort to conceptualise the new form of high speed globalised capitalism that others have more recently sought to understand through ideas such as neo-liberalism (Harvey, 2005) and totalitarian capitalism (Dufour, 2008). Otherwise, Empire was engaged in the exploration of the theoretical and practical possibilities embedded in the nascent form of post-modern anti-capitalism that had recently exploded onto the scene through the 1999 Seattle demonstrations. In the first instance, then, Empire seemed to capture the spirit of the times because of its effort to express first the rhizomatic nature of post-modern capitalism and second the ways in which popular movements set on the transformation of an enormously unequal world could make use of similar rhizomatic tendencies to change both their own local situations and the wider systemic structures of capitalism that always express themselves in some local context. In many respects Hardt and Negri's key thinkers, Deleuze and Guattari, were already concerned with the rhizomatic nature of capitalism, the ways in which the macroscopic tendency towards deterritorialisation related to the microscopic dimension of subjectivity, and whether it would be possible for the new fragmented subject, the schizophrenic, to ever transgress the turbulent spaces of capitalism. However, what Hardt and Negri managed to achieve in their work was a re-articulation of these issues which were already apparent in the 1960s for the new millennium when it seemed that the old Marxist theory of state capitalisms was no longer relevant to the reality of post-modernity.

But the cultural import of Empire extended further than its reflection on the relation between the empire of capitalism and the mass, or multitude, of producers who toil in order to maintain its structures. In the wake of the events of $9 / 11$ the position of Hardt and Negri's book shifted. It was now no longer simply a commentary on the struggles between trans-national capitalism and post-modern labour in global society, but rather an ultracontemporary meditation on the ways in which those struggles express themselves in social, political, and cultural positions that tend to evolve into paranoid fundamentalisms through their traumatic immersion in the apparent chaos of global space and then collide over how best to manage or resolve that turbulence. In the wake of 9 / 11 and the subsequent war on terror Hardt and Negri published another text, Multitude: War and Democracy in the Age of Empire (2004), that expanded upon their original text in order to take in the American-led invasions and occupations of Afghanistan and Iraq. But the problem with this text was that it never really immersed itself in the material realities of the social, political, and cultural expressions of global turbulence in sufficient depth. Instead Hardt and Negri remained wedded to the abstract scale of global space and failed to understand that a proper analysis of the realities of the contemporary global condition requires a consideration of the various scalings of the global, the local, and the individual and an exploration of the ways that these diverse scalings interrelate and interact. Thus 
Multitude simply reinforced the original message of Empire. That is that because contemporary global capitalism is entirely rhizomatic in nature and, therefore, impervious to old style top-down criticisms of this or that group, what is required is a new brand of horizontal, or rhizomatic, resistance able to function simultaneously at the level of the biopolitical, the national, and the global. In other words, Hardt and Negri explained that old style conflict theories, which locked the masses into a theoretical trajectory on the basis of a scientific study of the likely development of capitalism undertaken by the vanguard, needed to be rethought in order to take into account the new realities of post-modern capitalism. The problem was that this rejection of the politics of the vanguard in favour of a new brand of horizontal politics, or what Deleuze and Guattari $(1983,1984)$ call 'molecular revolution', requires a focus on localised conflict that Hardt and Negri were unable to deliver in Multitude.

Thus the scene shifts to a consideration of what I would consider the second key text of the contemporary epoch, Retort's Afflicted Powers (2005). Whereas the power of Empire resided in its ability to restate the key principles of Deleuze and Guattari's Capitalism and Schizophrenia $(1983,1984)$ for the 21 st century, the failure of Multitude was most clearly evident in Hardt and Negri's inability to apply the theory of the multitude to particular local struggles. In many respects Retort's Afflicted Powers completed what Multitude could not through its focus on the Iraq War as the scene of the wider struggle between the American-led Empire and the multitude, or people, who are always rooted in particular locations. Whereas Empire was powerful because it managed to produce a systematic theory of post-modern capitalism and Multitude was flawed because it failed to show how the struggles between empire and multitude played out at a local level, the precise contribution of Retort's book was that it was able to integrate a detailed analysis of the systemic nature of global capitalism and a consideration of the realities of the politics that condition the lives of people on a local scale. I think the reason for Retort's ability to re-scale Hardt and Negri's project is clearly related to the genesis of their project and that this point reflects a wider problem of the anti-capitalist movements that is not necessarily suggested by the authors of Empire and Multitude. First, let us consider the origins of Retort's project. Retort is a San Francisco based collective of critics, four of whom, Iain Boal, T. J. Clark, Joseph Matthews, and Michael Watts, produced Afflicted Powers, a text which evolved out of a pamphlet, 'Neither Their War Nor Their Peace', prepared for the San Francisco Anti-War marches of January-February, 2003. But how does this situation relate to the content of Afflicted Powers? I think that what the origins of Afflicted Powers illustrate is a level of engagement not necessarily present in Hardt and Negri's texts and thus illuminates perhaps the key problem of contemporary anti-capitalism which revolves around the question of how to match the neo-liberal, or totalitarian capitalist, mastery of scalings and transform a concern for systemic violence into radical political action on a local level.

We know that Empire is perfectly adjusted to the various scales operative in the network society through the webs of financial institutions, which constitute the global scale, policy mechanisms, such as structural adjustment programmes, which create neo-liberal states, and neo-liberal culture, which transforms cut-throat capitalism into common sense on a personal level. However, what Retort show in Afflicted Powers is how this apparent stranglehold on the various scalings of the global system was challenged by a spectacular event on $9 / 11$ which sent shockwaves through the imperial system and caused a backlash, which was similarly not only premised on its potential reality effect, but also heavily reliant on its ability to restate the symbolic value of the imperial order. Thus Retort's thesis is that the problem of scalings, which troubles contemporary anti-capitalism, can to a large extent be overcome by spectacular assaults on the symbolic basis of neo-liberal capitalism, precisely because it is at this symbolic level that Empire knits the levels of the global, national, local, and individual together. Essentially, Retort argue that the reason 9 / 11 was such an epochal event, which provoked the declaration of the war on terror, and later the emergence of the kind of war machine that Klein explores in The Shock Doctrine, is because it was captured live and replayed endlessly on TV screens across the world. From a psychoanalytic perspective it would be possible to suggest that the endless repetition of 9/11 was indicative of an attempt to symbolise an essentially traumatic event and thus insert it into the kinds of narrative structures that enable Empire to function, but the problem with this strategy is that the endless images of the ruins of the twin towers could only narrativise the attacks at the cost of amplifying the trauma caused by the initial reality effect of the event and thus further undercutting the symbolic integrity of Empire. As such, Retort show that the traumatic effect of 9 / 11 was too severe to be re-coded through basic symbolisation and that what was required to stabilise the symbolic structures of Empire was a spectacular backlash that would restore confidence in neo-liberalism and the capitalist way of life.

This point about the need to restore confidence is key because I think it illustrates an important point about the symbolic nature of reality in post-modern society. Consider Bin Laden's terror tactics. We know that terrorism is always meant to inflict maximum symbolic damage through localised physical violence simply because the commitment to 
spectacular destruction and the communication of panic, anxiety, and fear is written into the terrorists' strategy on a very basic level. We also know that this strategy was successful on 9 / 11 because the destruction of the twin towers seemed to expose the weaknesses of an apparently omnipotent social, political, economic, and cultural systemEmpire. This attack was, of course, a symbolic gesture, which the anti-capitalists will never be able to replicate because what they focus on is the moral deficiencies of neo-liberal globalisation, rather than its ability to function in the face of the enemy. In other words, anti-capitalists might be able to demonstrate that Empire is morally wrong, but they cannot currently undermine the cultural power of the capitalist system in the minds of the masses who live under its symbolic order. It is precisely this ability to order people's lives that Bin Laden and his suicide bombers believed they could throw into doubt. In my view the explicit nature of this excess of belief meant that $\mathrm{Al}$ Qaeda were in many respects successful in under-cutting the imperial symbolic order, to the extent that Empire felt the need to restate its authority through the exercise of massive military force, simply because it seemed that the Islamists believed in their cause more than the capitalist mass, whose symbolic system is structured by cynicism and disbelief, believed in their master signifier, consumer capitalism. Regardless of whether or not the notion of an Islamic super-state governed by Shari'a Law holds any more water than the anti-capitalist utopia of global society free from absolute poverty, the point remains that the Islamic utopians struck a blow to Empire, which artificially elevated their status to major players on the world scene, and enabled the neo-liberal utopians to cynically re-code non-violent moral criticism of the systemic violence of capitalism as somehow representative of a wider attempt to undermine normal everyday life in neo-liberal society. Even though the effort to bundle the nascent global left into debates on global terrorism may no longer work today, precisely because Empire and the Islamic utopians have both been found to be morally bankrupt in the Iraqi state of nature, that this strategy was successful for a number of years shows that the attacks on 9/11 had a very real effect on the symbolic structures of Empire. We know that Empire was shaken by the events of $9 / 11$. At the most immediate level mass media images of 'America under attack' fractured the symbolic structures of members of the liquid class across the world and caused them to retreat from the global sphere. I do not think we can underestimate the immediate psychological effects of the attacks on the twin towers because it is likely that it was the reaction-formation of a kind of bunker, or siege, mentality that caused detrimental effects at the global level of the neo-liberal economy which is so reliant on confidence to ensure first consumption in national markets and second the free circulation of finance across the global market.

Given this situation, Retort's view is that Empire was provoked to embark on the war on terror in order to defend its symbolic integrity on every level. However, this is not to say that their thesis is simply that the war on terror has never been anything but a post-modern public relations exercise conducted in order to convince the world of Empire's omnipotence. On the contrary, I would argue that the precise value of Afflicted Powers resides in the way in which it shows how the contemporary war on terror fuses a 'new fangled' post-modern concern for spectacle with the most brutal 'atavistic' interest in colonisation and what David Harvey (2003) calls 'accumulation through dispossession'. It is here, at the level of the real concrete, imperialistic strategies of Empire that Afflicted Powers advances the thesis of Empire and Multitude because it shows how following Bill Clinton's experiment with multilateralism, George Bush turned back to primitive myths of the American mission, embraced unilateralism, and as an effect brought Empire, the global network which is simultaneously everywhere and nowhere, back down to earth in America. In the wake of 9/ 11 it became less true that Empire was a global formation that was somehow independent of America and more the case that, to paraphrase John Locke, 'the whole world was America' (1980: 29), or at least that seems to be how the neo-liberal utopians understood the situation of America on the world scene. Apart from this relocation of Empire back to America, Retort also root what I think is a tendency to idealism in Hardt and Negri's work in other important ways. They argue that despite the new global space of flows, the hard currency of Empire remains guns, oil, and money. Thus they suggest that in order to really understand the current world situation we must recognise the ways in which post-modern sign value is rooted in the oldest kinds of capitalist violence, primitive accumulation or the seizure of land and raw materials and the oppression of native populations.

In order to conceptualise this combination of the post-modern concern with flows and immateriality and the modern interest in colonisation and imperial adventure Retort advance the idea of military neo-liberalism. Military neo-liberalism reflects the fusion of high speed deterritorialised capital and state interest in ensuring that that capital is able to access the most profitable territories and markets on the world map in a new form of imperialism or colonialism. As such, Retort take the Iraq War as a paradigmatic example of the exercise of military neo-liberalism on the contemporary world stage. In their view the initial aim of the colonial adventure in Iraq was to seize possession of Iraqi oil reserves, transform Iraq into a free trade zone, and thus establish capitalism in the Arabic Middle East. However, it is clear that Retort are also sensitive to the wider utopian project shot through the occupation of Iraq 
which was to transform Iraqi subjectivity through the wholesale reconstruction of the nation's culture in line with American ideas of freedom, democracy, and consumption. I think that this is, in itself, a key point because what it suggests is that American policy in what Derek Gregory (2004) calls the 'colonial present' is not simply driven by realpolitik, but rather conditioned by deeply held beliefs about what America means and how those meanings should be worked out on the world stage. For Retort the classic example of this condition, which illustrates that Empire is not simply determined by post-modern flows or the behaviour of the kind of Deleuzean schizo who is posthistorical and simply takes off on flights of fancy in order to escape molar formations, is the political relationship between America and Israel. They suggest that because it is difficult to understand the strategic value of Israel to America, since support for Israel has severely limited America's political options in an area of vital national interest, the American commitment to Israel must be rooted in some other emotional bond, which they link back to the origins of America itself. In Retort's view Israel occupies a particular place in the American political imaginary because it reminds it of its own origins. They suggest that the mythology of Israel is comparable to that of America, since like America, a nation founded in the wilderness in the name of God, it is possible to think of Israel as a kind of desert miracle, as the Holy Land carved out of the sand and rock of the Arabian wilderness. In this respect Retort's claim is that the relationship between Israel and America is founded on a common cultural, or mythological, basis and that this coincidence of foundation myths means that America is unlikely to ever abandon the Israeli state to the wolves of the Arabic wilderness. However, where I think Retort are mistaken is in their view that the mass media presentation of the Israel-Palestine war zone undermines the American mythology of Israel as a frontier state or desert miracle. In my view peace and stability are not characteristics one would associate with the frontier state. On the contrary, surely nothing is more definitive of the frontier state, the nation on the edge of the abyss, than the state of endless war.

The point of Retort's discussion of Israel is, therefore, two-fold. First, it shows how entwined symbolism and materiality are under conditions of Empire. In this first instance, we have seen that what Retort achieve that advances Hardt and Negri's position is a relocation of the immaterial, or deterritorialised, networks of Empire into particular, local, political situations, such as Iraq and the Middle East taken in the widest sense. However, what their discussion of the mythological dimensions of America's relationship to Israel illuminates is that the cynical politics of Empire are often determined by deeply rooted cultural values which, even though they differ from the kinds of spectacular performances, mass media images, and financial flows that characterise Hardt and Negri's global imaginary, are still of a different order to the hard currency of Retort's world system, guns, oil, and money. What emerges, therefore, in Retort's work is a dialectic of symbolism and materiality, or what they call 'new fangledness' and 'atavism', which shows how the symbolic order of the spectacle is bound to the materialism of the old order, where what matters is possession of land and raw materials, and the materialism of the old order is determined by the symbolic structures of deeply rooted cultural beliefs, such as the American belief in the chosen people and the Islamic belief in theocratic law, and mass media imaginaries, which present more or less powerful images of imperial coherence or incoherence. The progress of this new imperial dialectic, which we might choose to read through Walter Benjamin's (2003) image of the angel of history who is endlessly blown into a catastrophic future, is driven by on the one hand struggles over material possession, land, raw materials, and other physical goods, and on the other hand by efforts to control the impact of the mass media's representation of these struggles one way or the other. What this means is that when a blow is dealt to Empire in material terms, the mass media reflects the blows' effects in order to make sense of its impact. We know that it is precisely this process of narrativisation that terrorism counts on in order to spread panic in its target population. In response to the introduction of the contagion of fear we know that Empire responds through material violence. The use of overwhelming military force is deemed necessary in order to save face and prevent further detrimental reality effects brought about by panicky responses to the initial spectacular offence. Finally, the discourse of self-defence functions as a pretext to allow Empire to advance its own cause on the world stage and engage in further colonial expansion. All of this is then wrapped up in a new imperial imaginary which emphasis first the awesome power of Empire, because it is usually Empire, rather than America, that we confront on symbolic terrain, and second the universal validity of imperial ideology, committed to democracy, freedom, and human rights. The two-fold objective of this strategy is, therefore, to stabilise the imperial project on the symbolic level and as a result to enable its advance in material terms.

Given this thesis, which shows how imperial power is entirely reliant on the integrity of its image to secure its material future and vice versa, Retort extend their argument by showing how the other big player on the current world scene, the Islamic utopians, have founded their own politics on a similar basis. In other words, Retort construct a dialectic of violence based on the commonality of two ideologies, which although they may be completely 
asymmetrical in terms of material power, are equally committed to global expansion. Consider the structure of this dialectic of violence. The Islamists are geared up to attack Empire through the spectacle, simply because this is how terrorism must function, in order to defend their own symbolic structures from invasion by western or, perhaps more precisely, neo-liberal ideology. We know that this violence necessarily provokes further spectacular responses from Empire, which cannot tolerate symbolic offence because of the effects of such attacks on its image of omnipotence, which necessarily provokes further spectacular violence from the Islamists, who are committed to spectacular violence and so on ad nauseum. Since both Empire and the Islamic fundamentalists constitute themselves as utopian or totalitarian symbolic systems unable to tolerate co-existence, Retort see no end to the war on terror. In other words, they seem to suggest that we are locked into an endless struggle between two cultures set on the symbolic, if not material, colonisation of planetary space. That this struggle is conditioned by a dialectic of spectacular and material offence ensures that the asymmetrical nature of the military forces of Empire and the Islamic fundamentalists is unlikely to ever tip the balance in Empire's favour, since how the struggle plays out in terms of spectacle is equally if not more important than how it progresses in purely material terms. This is the case simply because what is at stake in the war is not only the possession of precious resources but also symbolic integrity and as a consequence cultural power.

This is why I think it makes sense to talk about the war on terror in terms of a clash of utopias, because what we refer to when we talk about utopia is the idea of total cultural hegemony premised on a completely coherent symbolic, or textual, order rather than some kind of pure material totalitarianism that exists beyond the kinds of social, political, and economic struggles that define the base level of reality Lacan (2007) talks about through the notion of the real. This is also why I think John Gray (2007) is mistaken in his recent book Black Mass when he declares the death of utopia. Contrary to what Gray believes, I think that it is unlikely that utopia will expire in the war-torn cities of Iraq because the Imperial utopians and Islamic fundamentalists will somehow come to realise that their symbolic structures are bankrupt and that they cannot be translated into material reality, since the entire war is about the desperate defence of symbolic structures through a kind of ontological violence, which has far less in common with Machiavellian ideas about means and ends than it does with Hobbesian or Nietzschean conceptions of the originary nature of struggle and warfare. In this respect we might suggest that the Imperial and Islamic utopians feel that they have little choice but to continue to fight it out in the cradle of civilization because what they are caught up in is a zero-sum game where they either maintain their utopian beliefs through struggle or see these ideas lose their legitimacy and suffer the consequent collapse of their symbolic orders.

Simply because endless struggle ensures the maintenance of symbolic integrity, and as a result the continuation of utopian symbolism, the fact of the endless struggle itself is unlikely to ever impact upon the life of utopian cultural formation, unless of course we want to say that the war is likely to strengthen the desperate belief in symbolic unity and, as a consequence, result in more intense struggle and so on ad infinitum. That this is, I think, the essence of Retort's thesis makes their claim that the war-torn symbolism of the Israeli state somehow undermines the symbolic structures of Empire difficult to understand. Apart from the technical point, which suggests that the cultural structures of the imperial symbolic order are unlikely to simply cave in under pressure of material reality but rather harden to stimulate further struggle and so on, we know from Retort's book that the special relationship between Israel and America is based on a common sense of exceptionalism which turns off theological ideas of chosenness that condemn both peoples to struggle with evil forces until the turn of the millennium. When we recognise that this notion of the ontological status of martial law is so deeply rooted in both Israeli and American culture, that it has translated through the histories of both peoples in the form of struggles for survival in the face of various incarnations of the wilderness, and that it occupies an essential place in the neo-liberal mindset which elevates competition and everyday struggle to the status of a philosophical imperative, it should be easier to understand why Gray is mistaken in his view of the end of utopia, since realisation of endless struggle is unlikely to undermine the belief in a symbolic order committed to struggle, and realise the limitation of Retort's claim that the media representation of Israel-Palestine impacts upon the symbolic coherence of Empire.

That is to say that where Retort are mistaken is in their view that Empire somehow needs peace to ensure symbolic integrity. On the contrary, I think that what Empire requires is endless war to secure a symbolic order characterised by the idea of struggle and that the problem of $9 / 11$ was that it threatened to destabilise the practice of struggle itself by raising the stakes of the endless warfare beyond the level of everyday practice (Baudrillard, 2002, 2005). Thus the war on terror represents an attempt to meet Al Qaeda's stake and intensify struggle on an everyday basis. That Al Qaeda are also committed to a utopian mythology of endless struggle, the Jihad, only further strengthens the imperial commitment to the idea of the neo-liberal dreamworld, what Pierre Bourdieu (1998) calls the utopia of 
unlimited exploitation. In my view, then, the limitation of Retort's project resides in their failure to properly explain the ways in which these two utopian projects support each other through their violent confrontations. This is where I think Naomi Klein (2007) advances Retort's thesis in that she shows how the imperial project is not committed to the production of a stable utopia, but rather that it is totally reliant on the turbulence of warfare to sustain the symbolic structures of neo-liberal culture. Although the existence of the Islamic utopia is more or less absent from her account of the emergence of a new form of terroristic capitalism, I think that is because she thinks that other utopian movements are largely the by-product of a martial culture that requires similarly inflexible oppositional ideologies to produce conditions of war to grease the wheels of a social, political, and economic system reliant on ontological insecurity to sustain itself. I explore Klein's thesis in the following section of the paper.

\section{The Utopia-Dystopia of Disaster Capitalism}

What Klein proposes in her book The Shock Doctrine (2007) is a theory of what Lieven De Cauter (2004) calls entropic Empire. I think that this thesis represents an advance on Retort's theory of a world system shot through with spectacular violence because what the San Francisco writers miss that Klein understands is the ways in which violence and turbulence have become normal to the neo-liberal system that requires local disturbances to power economic vitality, social struggle, and the symbolic, or cultural, structures set-up to champion ideas of cut-throat competition through support for democratic goods, such as freedom, individualism, and self-realisation. In this respect Klein's thesis is perhaps closer to Hardt and Negri's original Empire (2000), since her theory of the necessity of turbulence in neo-liberalism reflects their use of Deleuze and Guattari's $(1983,1984)$ paranoia-schizophrenia complex, which shows how capitalism requires conflict to generate innovation, or what they call deterritorialisation, in order to prevent the stagnation of the economy in totally paranoid social, political, economic, and cultural formations. As such, we might say that Hardt and Negri's Empire was always already an entropic Empire and wonder what Klein's book brings to the table. The answer is that where Klein's book supplements Hardt and Negri's work is in her enormous effort to connect the global theory of turbulence to endless examples of local chaos drawn from national and intra-national urban scalings. Following this recognition we can see that Klein extends Hardt and Negri's theory of entropic Empire through a sensitivity to the kinds of local scalings that Retort appreciate, but that she also expands upon Retort's image of a world system scarred by the kinds of violence endemic to the structures of the entropic Empire by restating Hardt and Negri's key point, which Retort fail to emphasise, which is that violence and warfare are not aberrations in the contemporary world system but rather representatives of the central principle, turbulence, which ensures that system's future vitality. What this means then is that Klein's Shock Doctrine represents a kind of dialectical synthesis of Hardt and Negri's Empire and Retort's Afflicted Powers which presents a truly terrifying image of the contemporary neo-liberal Empire, the new brand of capitalism she calls disaster capitalism.

In his review of The Shock Doctrine Michael Hardt (2007) suggests that what Klein misses in her theory of a new form of violent capitalism is the way that capitalism was always reliant on destruction to ensure economic vitality and the production of surplus value. In order to support this claim he points to Marx's (1990) idea of primitive accumulation, which is central to Retort's thesis, Luxemburg's (2003) work on accumulation and expansion, and Schumpeter's (1984) theory of creative destruction, but he might also have referred to his own work with Negri, Empire, and centrally Deleuze and Guattari's $(1983,1984)$ classic two volume study, Capitalism and Schizophrenia. Although I think that Hardt is correct, in that each of these writers recognises the relationship between capitalism and violence, what Klein contributes to their insights is the idea that war, violence, security, and insecurity are no longer the means to the end of the extraction of surplus value but rather the end of the production of surplus value itself. In others words, in Klein's theory of disaster capitalism it is not only that capitalism embarks on colonial adventure, and as a consequence military expeditions, in order to extract surplus value from resource rich lands, but that the very production, prosecution, and resolution of warfare has become the engine for the production of surplus value. In other words, warfare is no longer the means to support the end of extraction, but rather a process which generates a reservoir of surplus value quite distinct from the fund produced by the traditional practices of colonisation and exploitation. More serious than Hardt's critique of the Shock Doctrine thesis, which I think Klein covers when she talks about the post-modern nature of the disaster capitalism complex which has closed the loop of the practice of primitive accumulation by becoming its own source of surplus value, is the essential problem thrown up by the new model of profit creation through warfare which currently plagues the home base of Empire, America. 
What is this problem? The problem I refer to is rooted in the effect of the transfer from a focus on the efficient extraction of surplus value through primitive accumulation to a concern for the extraction of primitive accumulation rooted in martial practices set on the creation of surplus value through the production, prosecution, and resolution of war itself. What does this mean?

In the past the objective of colonial adventure was the extraction of surplus value from foreign lands. Thus it was reasonable to assume first that this practice would be concerned with the efficiency of extraction and second that the colonial state would obtain some benefit from this process simply because state force was necessary for capitalists to engage in large scale extraction projects. However, in Klein's model of disaster capitalism-which I believe is a more or less accurate reflection of George Bush's neo-liberal warfare state-neither of these assumptions hold since first the extraction of surplus value from primitive accumulation is not the only objective of colonial adventure, because as we have seen war is now a creative industry in its own right, and second the state can no longer expect to obtain any benefit from the process of primitive accumulation, since many of its functions are now under the jurisdiction of corporations that specialise in warfare and security. At this point the reader may wonder if I am concerned with whether colonial adventure is carried out with the proper concern for efficiency or not, rather than the morality of the extraction of surplus value from foreign lands. But this is not in fact the case. What interests me above all about the issue of profit creation in Klein's model of disaster capitalism is the way that it turns off a theory of how neoliberalism manages to use warfare to redistribute wealth through both the exploitation of the global south by the global north and the poor majority in the global north by the super rich minority in same sphere of the world. The key point to emphasise here is the neo-liberal transition from policies of colonial adventure set on the extraction of surplus value which were committed to primitive accumulation for state benefit to policies of colonial adventure set on the extraction of surplus value through primitive accumulation and the practice of war itself for private benefit. It is clear that both the colonised state and the coloniser state lose out in the later scenario. Whereas the colonised state suffers the kind of rape common to traditional imperialism, the coloniser state is subject to a new second order form of pillage whereby the state is not simply excluded from the immoral rape of foreign lands but actively supports private accumulation through the reallocation of state funds into private hands.

This is exactly the kind of privatization process that Klein outlines in the Shock Doctrine. In fact if we supplement our consideration of Klein's book with study of Michael Schwartz's (2007) paper on the rape of Iraq's cities, Neoliberalism on Crack, what emerges is a horrifying picture of the production and prosecution of the war in Iraq, the evolution of processes of primitive accumulation, and the corruption of the reconstruction effort. In Klein's view there can be little doubt that the war was driven by the desire to open the Middle East to specifically American capitalism, since other national capitalisms were excluded from the feeding frenzy that took place in the wake of the war, a situation which incidentally complicates Hardt and Negri's theory of Empire and post-modern capitalism, but this is not the end of the story. We know that the colonial adventures of contemporary disaster capitalism are not simply repetitions of old style imperialisms. As Schwartz shows, in the case of Iraq the extraction of surplus value from the oil fields, which was meant to generate revenue for the reconstruction effort, has been hampered less by the resistance of insurgents, who are simultaneously absolutely utopian and desperately realistic in their efforts to resist the raids of the military neo-liberals and more by the corruption of American corporations who have always had one eye on the continuation of the war as a means to the end of the production of endless surplus value.

The same logic applies to the reconstruction effort. Both Klein and Schwartz show how trans-national corporations made use of the same kinds of corrupt practices, such as the artificial inflation, extension, and expansion of contracts, that served other companies so well in the war effort to increase their profit margins. The kinds of contracts drawn up between the state and private business to provide logistical support to the military, offer private security, and co-ordinate the reconstruction effort leave little room for doubt about the state interest in the privatization of conflict. If we take the famous example of the cost plus contract, whereby corporations' costs were covered plus a secure profit, it is hard to sustain the argument that the Iraq War was simply about the privatization of conflict, because there is little sense of competition or risk written into these contracts. On the contrary, I would suggest that such evidence suggests that disaster capitalism cannot be seen to reflect official neo-liberal ideology, which is bad enough in its celebration of private interest but rather its obscene, corrupt, underside, committed to the redistribution of wealth to the super-rich and the expansion of class inequalities across the world. In this respect the disaster capitalist state is less concerned with the celebration of open competition in pursuit of scarce resources, which could be seen to equate to the emergence of a global Hobbesian war of all against all over limited riches, than it is with the security of the interests of what Klein calls the corporate class, the class that reflects the complete fusion of big business and political elites. 
Given the existence of the corporate class, it is clear that there is no freedom of competition in the disaster capitalist state. Thus we might conclude that the official ideology of neo-liberalism, which turns off the idea that we should celebrate brutal conflict and natural inequality in civilized society, is a sham. As such, it is not only that we now have no welfare state, since the World Bank and IMF tell us that management of the economy is corruption of the economy, but that the start of the 21st century has seen the emergence of the welfare state's evil twin, the warfare state, which regards war and natural catastrophe as opportunities to engage in plunder, corruption, and the redistribution of wealth from the poorest to the richest sectors of society. This is Klein's thesis in a nutshell. In terms of her conclusion that the warfare state is committed to the redistribution of wealth from poor to rich, she is in agreement with David Harvey (2005), whose history of neo-liberalism summarises the rise of this new form of capitalism, but where Klein extends Harvey's work is in her connection of neo-liberalism to warfare, catastrophe, and chaos. In her view chaos is today's big business. Chaos opens up the Hobbesian state of nature, which is in itself the natural model of pure capitalism and enables the champions of neo-liberalism to fill its institutionless void with regulation set on the legalisation of brutal struggle. Although Hobbes name never appears in The Shock Doctrine, I think he is the philosophical father of Klein's central concept, disaster capitalism. Consider Hobbes' key work Leviathan (2007). Is disaster capitalism not about the destruction of the Keynesian state and the creation of a neoliberal world system through the endless repetition of Hobbes' theory of the birth of society? Hobbes tells us that before society existed there was chaos, the state of nature. The Leviathan, sovereign power, imposed law upon the state of nature in order to regulate the behaviour of men. Beyond the prevention of total violence, which would lead to the collapse of political society, the Leviathan would allow men freedoms, but what he would not allow would be the freedom to change the system itself.

In neo-liberalism Hobbes' pre-social chaos is produced by either war or some natural catastrophe. Sovereign power, the neo-liberal elite, then roll into town to impose new order onto the chaotic situation. They impose neoliberalism upon the native population, who have by this time become natural savages, and then legalise this ideology on the basis that it is the best way to manage society. The sticking point is, of course, that Hobbes' theory of the state of nature was only ever a thought-experiment meant to apply to some originary condition before society had been invented in the first place. How, then, can this model be applied to neo-liberalism, which seems committed to regime change in order to further its objective of a worldwide corporate utopia? The answer to this question is that we have to think about Locke's (2003) key addition to Hobbes' original model of the liberal society. Locke took Hobbes' original theory of the Leviathan and provided men with the right to overthrow the sovereign and install a new regime if the living God violated their natural rights to life, liberty, and property. What we have here is the model for neo-liberal ideology and the theory of regime change with Empire installed as representative of the people oppressed by the violent Leviathan. Although the necessary theory of political economy was introduced later by Adam Smith (1998), who spoke about the invisible hand of the market and the idea that individual greed could somehow benefit everybody, Friedrich Hayek (2001), who opposed the notion of the free market to the reality of Communist unfreedom, and Milton Friedman (2002), who repackaged these ideas in a theory of the scientific validity of laissez faire capitalism and then tried to sell it to successive American presidents, I maintain that the ideological roots of Klein's theory of disaster capitalism reside in the strange fusion of Hobbes and Locke expressed in the works of Hayek and Friedman.

It may be that for the best part of the 20th century disaster capitalism was more or less held in check by the existence of Communism and the capitalist elite's recognition that it need to appease the have nots to prevent them turning red, but as the century drew to a close this barrier was no longer effective. In the wake of the failure of the left, Klein explains that the capitalist elite embarked on their plan to neo-liberalise the entire world through the medium of chaos. She begins with a consideration of New Orleans and the effects of Hurricane Katrina. In her view Katrina presented the neo-liberal utopians, who are committed to the creation of a pure capitalist world, with the perfect opportunity to impose a new Hobbesian settlement upon the people of New Orleans. In other words, the catastrophe of Katrina transformed New Orleans into a state of nature, or tabula rasa, and the disaster capitalists were quick to exploit the situation. As the reconstruction effort took effect state schools became private schools and the entire infrastructure of the city was privatized under cover of public trauma. This later point about the 'cover of trauma' is essential because it explains the title of Klein's book. Klein's thesis is not simply that chaos is the new market for corporate utopians. The first step in Klein's theory is that chaos is necessary to the transformation of social welfare states that limit extremes of poverty and wealth through legislation and regulation into warfare states that create extremes of poverty and wealth through legislation and regulation which institutionalise the state of everyday war that feeds the neo-liberal disaster capitalist complex. Her point here is to suggest that explosions of 
chaos and catastrophe tend to undermine the ability of people to resist processes of neo-liberalism and that the corporate utopians have understood that shock is a useful tool for the implementation of catastrophic reform.

In many ways this idea suggests a new theory of the ways in which neo-liberal, or totalitarian, capitalism has achieved mastery over the diverse scalings of contemporary reality, since what Klein's thesis offers is a theory of the ways that the ideology of neo-liberal globalisation feeds through state policy to the psychological transformations of individuals who must then endure the new neo-liberal reality they find themselves occupying. Although I am not sure Klein is wholly successful in this effort to provide a comprehensive theory of the connections between of scalings of our novel neo-liberal reality, simply because she is clearly not versed in the works of Lacan and thus cannot offer an integrated theory of the ways in which our lives are ordered by the symbolic systems that surround us, I think she presents an interesting analysis of processes of subjective transformation under neo-liberal capitalism. The Lacanian thinker Dany-Robert Dufour (2008) covers similar terrain in his book The Art of Shrinking Heads, but where Dufour connects the evolution of neo-liberal culture, which destroys people's ability to think critically about the world, to the rise of shopping and consumerism, Klein links the emergence of neo-liberal man to torture and the production of schizophrenic subjectivity. That is to say that where Dufour focuses on expansion of the culture industries and the commodification of everything, Klein considers a series of CIA experiments conducted in the 1950s set on the discovery of the psychological techniques necessary to re-pattern individuals.

In this way Klein shifts from a discussion of a particular episode of psychological torment, which caused the collapse of the psychic structures of particular individuals, through large scale shock therapy, meant to de-pattern individuals on a mass scale, to the emergence of what Lieven De Cauter (2004) calls entropic Empire, a convulsive world system that produces individuals who are either in a state of constant shock or evolve into perfect schizo capitalists able to roll with the blows of the new world dis-order. Reading Klein's book it seems clear that neo-liberal man is a miserable, tortured, creature. In Klein's work there is no happy schizo who, in Deleuze and Guattari's language, takes flight whenever it appears that they are likely to find themselves stuck in some molar formation or other, but rather millions of old style Freudian (1989) subjects who need civilization to structure their lives. For evidence of the continued existence of the Freudian subject we simply need to consider how neo-liberal man has responded to the privatisation of civilization. He has not welcomed this process by transforming himself into a desiring machine, even though champions of the culture industry would say that that is exactly what the excessive subject of contemporary late capitalism has become, but has instead fallen into a state of paranoia. Of course, this is exactly what Klein's monstrous system requires of neo-liberal man. The schizo subject, fearful of the outside world, in need of consolation, turns to the universe of commodities produced by the culture industry, and his specially constructed fortified community produced by the security industry, for comfort and protection from those less fortunate schizos, who want similar relief and protection from the endless shocks of convulsive capitalism. Perhaps I have mis-understood Deleuze and Guattari's Schizophrenia and Capitalism (1983, 1984), but I am sure that this desperate situation is not what they had in mind when they wrote about the potential of the schizo to escape the paranoid formations of capitalism.

Far from transgressing paranoid formations it is clear that the contemporary neo-liberal schizo produces bunkers, walls, fortified communities, panic rooms, and surveillance systems in excess. In light of this explosion of paranoia the Belgian urbanist Lieven De Cauter (2004) claims that we live in a capsular civilization. In his view this paranoid culture, characterised by expressions of anxiety and fear, is perfectly suited to the new brand of capitalism, which is geared to the creation and management of chaos. Consider the contemporary global homeland security industry. Klein explains that this industry, which takes in the most unequal societies in the world, America, South Africa, Brazil, and Israel, is now even more profitable than the home of Adorno and Horkheimer's (1997) culture industry, Hollywood. Moreover, she tells us that the masters of security, the Israelis, have proven that the traditional rule, which suggests that chaos and economic vitality are opposites that cannot co-exist, is no longer operative in the contemporary world. In 2007 the performance of the Israeli economy was comparable to that of the Chinese and Indian boom economies because, in her view, the security corporations, such as the wall builders Magal and Elbit, were so profitable. Thus we live in a security bubble, conditioned by mass surveillance, mass incarceration, urban warfare, eroded civil liberties, and legitimate torture, which requires the production of catastrophe to ensure its continued vitality.

Given this view, let us once more emphasise the problem with Retort's (2005) idea that the situation in IsraelPalestine is somehow detrimental to the symbolic coherence of Empire. The endless war between Israel and Hamas is clearly not problematic to either Israel or the American Empire because it enables Israel to maintain its 'competitive advantage' in the homeland security market and America to keep its foot in the door of the same market. Where 
would the war on terror be without Israel-Palestine? All of this sounds like an enormous conspiracy theory. Surely it is insane to suggest that the situation in the Middle East is driven by economic considerations and that American interest in the area is conditioned by its desire to stimulate profitable chaos? The truth is that to see the rise of the disaster capitalism complex in the Middle East as a vast conspiracy theory thins out the evolution of the situation, underestimates the deep cultural connections between Israel, America, the idea of the frontier, and capitalist ideology suggested above, and misses the ways in which the new catastrophic form of capitalism emerged as an adaptation to already existing chaos in the region. What does this mean? Klein's thesis is that disaster capitalism was extended to the Middle East in its completed state to take advantage of pre-existing chaos and expand American influence in the area. In other words, her view is that disaster capitalism came to Israel, Iraq, and the Middle East late, but that when it did emerge it took the form of a fully integrated system set on the extraction of surplus value from the production and exploitation of violence, destruction, and misery. In this respect discussions of the exploitation of urban war in Israel and Iraq and natural catastrophe in Indonesia, Thailand, the Maldives, and New Orleans represent the pinnacle of contemporary disaster capitalism in Klein's account. But what about the origins of this new brand of capitalism? Where did disaster capitalism begin?

Beyond her consideration of the CIA's experiments in torture, which set the scene for discussions of social deconstruction-reconstruction in the service of American capitalism, Klein focuses on Latin America in the post World War II period and in particular American fear of the potential of developmentalism to foster pro-communist sentiments in the Latin American masses. In response to these fears Klein shows how the CIA sponsored military dictatorships in Chile, Argentina, and Brazil and encouraged these regimes to implement neo-liberal economic reform. Since the Friedmanite reform programmes of the so-called Chicago Boys, the Chicago trained economists put in place to neo-liberalise the Latin economies, caused wide-spread poverty, misery, and hardship Klein explains that it was necessary for the military regimes to support them with brutal violence and indiscriminate terrorism. Thus the first example of the implementation of the shock doctrine entailed economic transformation through planned violence and organised terrorism. Violence became the means to the end of economic re-organisation and the redistribution of wealth from the poorest classes to the rich elites. But by the 1980s state violence was no longer the only engine of the American sponsored process of neo-liberalisation. In the early 1980s Margaret Thatcher embarked on the privatization of British society on the basis of success in the Falklands War. As the decade wore on Thatcher's policy of privatisation was coupled with attacks on organised labour, the de-regulation of business, and the reduction of state welfare.

As the 1980s became the 1990s Klein tells us the neo-liberal system was ready to begin the transformation into full scale disaster capitalism. Following the fall of the Berlin Wall and the collapse of the Soviet Union, first Russia, then China, Poland, Mexico, South Africa, and the Asian Tigers fell foul of the neo-liberal system set on the exploitation of chaos. Although in Klein's view it would be a mistake to imagine that the viral infections of the globalised neo-liberal system in the 1990s, most clearly evident in the economic collapse of the Asian Tigers which was correctly titled 'Asian Flu', were somehow natural catastrophes, since in the Friedmanite view the global economy needs convulsions, crashes, and shocks to drive innovation, creativity, and the production of surplus value, she does not think this is enough to qualify these episodes as examples of the intervention of disaster capitalism. The reason for this is that even though the notion of the productivity of chaos, which is perfectly symmetrical with Schumpeter's (1984) idea of creative destruction, was present in the 1990s there was no clear sense that chaos could be engineered for the sake of the creation of surplus value. Thus Klein suggests that the final step in the emergence of the fully reflexive entropic empire was the invention of disaster capitalism proper, a complete social, political, cultural, and economic form set on the promotion, production, and exploitation of chaos on a global scale. Does this mean, then, that we should regard the Iraq War as the classic example of the disaster capitalism complex? I think that we must support this conclusion because it is only really in Iraq that we find the complete package of the promotion, production, and exploitation of chaos without outside intervention from natural catastrophe, quasi-natural economic crash, or entrenched political conflict ripe for insertion into the disaster capitalism complex.

However, while I think we must consider the Iraq War and consequent occupation the originary case of the disaster capitalism complex, I also think that we must qualify this conclusion with the assertion that there is no sense in which Klein's model is necessarily particular to the Iraq case. On the contrary I think we must consider fully fledged disaster capitalism a global phenomenon and imagine that even if there are less examples of planned catastrophe of the magnitude of Iraq, which was planned, produced, and executed for the sake of profit, in the near future, simply because the rape of Iraq has been so overwhelmingly unpopular with the masses, the exploitation of unplanned shocks, such as the Asian contagion, for the sake of private profit is likely to continue unabated. In light 
of this possibility I think that the real value of Klein's work resides in her intuitive if not theoretical understanding of the ways in which the entropic Empire fosters chaos, communicates the effects of shocks, crashes, and catastrophes through the various financial and mass media networks which make up what we might call the world system to national capitalisms, which then communicate these effects to individuals who seem to stand naked before the monolithic entropic Empire. Herein resides Empire's mastery of the scalings of the contemporary global network, a mastery which means that those who choose to talk about a new brand of totalitarian capitalism (Dufour, 2008) are entirely legitimate in their claims, on the basis that what the neo-liberal utopians have achieved in their manic pursuit of a perfectly smooth form of global capitalism is a world system which is permeated by capital and the wild fluctuations of the market on every possible level.

But if the idea of this system, the Hobbesian-Lockean-Friedmanite cultural construct which suggests that the free market is some kind of Ur-social formation evidenced by both God and western science, represents a utopia for the rich, it is most certainly a dystopia for the poor who must suffer the production of profitable chaos and planned misery. Unlike the rich, who reap the financial rewards of chaos, through their involvement in the neo-liberal disaster capitalist complex, and then buy their way out of the entropic conditions which come to characterise their own societies, the poor have no choice but to fight for survival in the state of nature which continues to fund the excessive lives of the elites. Where will this end? In the final pages of her book Klein suggests that the signs are that the disaster capitalism complex, which taken in its broadest sense means a brand of capitalism set on the extraction of profit from chaos, might come to end in the place where it began, Latin America. That is to say that she finds hope in the rise of the socialism of Hector Chavez and Evo Morales, who similarly propose a new utopia which values human life over money to oppose the contemporary utopia-dystopia of disaster capitalism which values money over every other good. Otherwise I think we might look to anti-capitalism and the motto, another world is possible, for hope for the future. Although Klein never expands upon the possibilities for change in her book, I think that reference to the anti-capitalist movement is key because what contemporary movements, or spaces, such as the World Social Forum, suggest is a reversal of the scalings of neo-liberal capitalism, which always lead from the global through the local to the individual in such a way that ensures the complete subordination of the minor scalings to the monolithic global system, through a focus on individual political participation and the ways in which these kinds of contributions might inform first local, second national, and third global politics. This focus on individual participation and local politics would, of course, offer a possible solution to the brutality of contemporary neo-liberalism because it would re-scale the world system to the level of humanity and place the monolithic network firmly under the control of local communities. The cynic might say that this is a fantasy. At the moment I would have to agree that the idea that the World Social Forum could effectively oppose the neo-liberal disaster capitalist complex is truly utopian, in that it would take an enormous leap of faith to even imagine such a possibility, simply because the organisational structures are not in place to transform the multitude who currently suffer under disaster capitalism into a coherent body able to oppose the neo-liberal utopians across the scalings of the world system, but then who would have thought that millions of people would take to the streets in protest of the plan to create Iraq Inc, disaster capitalism's utopiadystopia in the Middle East.

\section{References}

Adorno, T. and Horkheimer, M. (1997) Dialectic of Bourdieu, P. (1998) 'Neo-liberalism, the Utopia (Becoming a Enlightenment. London: Verso.

Baudrillard, J. (2002) The Spirit of Terrorism. London: Verso. Reality) of Unlimited Exploitation' in his Acts of Resistance: Against the New Myths of Our Time. Cambridge: Polity. Pp. 94-106

Baudrillard, J. (2005) The Intelligence of Evil or the Lucidity Pact. De Cauter, L. (2004) The Capsular Civilization: On the City in Oxford: Berg. the Age of Fear. Rotterdam: Nai Publishers.

Benjamin, W. (2003) 'On the Concept of History' in his Selected Writings: Volume 4: 1938-1940. Cambridge, MA: Belknap Press. Pp. 389-401.

Deleuze, G. and Guattari, F. (1983) Anti-Oedipus: Capitalism and Schizophrenia: Volume I. London: Athlone. 
Deleuze, G. and Guattari, F. (1984) A Thousand Plateaus: Capitalism and Schizophrenia: Volume II. Minneapolis: University of Minnesota Press.

Dufour, D-R. (2008) The Art of Shrinking Heads: On the New Servitude of the Liberated in the Age of Total Capitalism. Cambridge: Polity.

Freud, S. (1989) Civilization and its Discontents. New York: W. W. Norton.

Friedman, M. (2002) Capitalism and Freedom. Chicago: University of Chicago Press.

Gray, J. (2007) Black Mass: Apocalyptic Religion and the Death of Utopia. New York: Penguin.

Gregory, D. (2004) The Colonial Present: Afghanistan, Palestine, Iraq. Oxford: Blackwell.

Hardt, M. (2007) 'The Violence of Capital'. New Left Review, 48, November-December. Pp 153-160.

Hardt, M. and Negri, A. (2000) Empire. Cambridge, MA: Harvard University Press.

Hardt, M. and Negri, A. (2004) Multitude: War and Democracy in the Age of Empire. London: Penguin.

Harvey, D. (2003) The New Imperialism. Oxford: Oxford University Press.

Harvey, D. (2005) A Brief History of Neoliberalism. Oxford: Oxford University Press.

Hayek, F. (2001) The Road to Serfdom. London: Routledge.
Hobbes, T. (2007) Leviathan. London: Penguin.

Klein, N. (2007) The Shock Doctrine: The Rise of Disaster Capitalism. New York: Metropolitan Books.

Lacan, J. (2007) 'The Function and Field of Speech and Language in Psychoanalysis' in his Ecrits. New York: W. W. Norton. Pp 197-269.

Locke, J. (1980) Second Treatise of Government. Indianapolis: Hackett

Locke, J. (2003) Two Treatises of Government and A Letter Concerning Toleration. New Haven: Yale University Press.

Luxemburg, R. (2003) The Accumulation of Capital. London: Routledge.

Marx, K. (1990) Capital: Critique of Political Economy: Volume I. London: Penguin.

Retort. (2005) Afflicted Powers: Capital and Spectacle in a New Age of War. London: Verso.

Schumpeter, J. (1984) Capitalism, Socialism and Democracy. London: Harper.

Schwartz, M. (2007) 'Neo-liberalism on Crack: Cities under Siege in Iraq’. City, Volume 11, Issue 1, April. Pp 21-69.

Smith, A. (1998) Wealth of Nations. Oxford: Oxford University Press. 